\title{
Investigation and Research on Experimental Teaching Reform of Sports Health Care in Universities
}

\author{
Hongpin Zhang \\ School of Sports and Health, Linyi University, Linyi, Shandong Province, China
}

Keywords: sports health care; experiment; reform; combination of sports and medicine

\begin{abstract}
In this paper, research on experimental teaching reform is carried out through experimental teaching and questionnaire survey of 88 students from the School of Sports and Health, Linyi University. The research results show that the new experimental teaching mode of "combination of sports and medicine" is better than the traditional teaching form in improving students' experimental skills and enhancing the rates. Thus, this paper suggests that, the new experimental teaching mode based on the "combination of sports and medicine" should be adopted widely to improve students' experimental skills.
\end{abstract}

\section{Introduction}

Sports health care is a comprehensive applied science which studies the health care patterns and measures in the process of sports; it is an interdisciplinary subject which develops with the combination of sports and medicine. [1] Sports health care covers basic theory knowledge of human movement like sports anatomy, sports physiology and sports biological chemistry; it also involves medical knowledge and skills like preventive medicine, clinical medicine and rehabilitation medicine. It is a theory course with strong practical. The course covers theoretical and practical knowledge of exercise and nutrition, medical supervision, movement disorders, sports injury, emergency, massage and other aspects. It is widely used in medical supervision, sports education, sports training and competition, sports injury identification, diagnosis, prevention and treatment, as well as the diagnosis and first aid of sports injury. Thus, a significant feature of this course is training students' practical abilities on sports health care during the teaching process. The traditional sports health care experiments are formalistic and simple in content, which cannot meet students' needs on working and scientific research [2]. Most experiments are basic or comprehensive experiments, rather than open and innovative experiments. In an experimental class, teachers need to explain the experiment first, and then students are asked to complete the experiment according to teachers' explanation step by step. Students do not have enough interests in this kind of experiment. As for experimental assessment, the evaluation system of experimental skills and operation levels is not scientific, and cannot truly reflect students' practice levels [3]. This paper compares the traditional experimental teaching mode and the innovative experiment mode, striving to find an experiment mode which can adapt to the specific situation of School of Sports and Health, Linyi University, in order to improve the experimental skills of our students, and help them to do better in future works like physical education, sports training, competition guidance and comprehensive fitness guidance.

\section{Research Objects and Methods}

\subsection{Research objects}

Undergraduate students who major in physical education and health, and has been learned in the School of Sports and Health of Linyi University since 2015 serve as the research objects to study the teaching effects of a new experimental teaching type based on "combination of sports and medicine". 


\subsection{Research methods}

Document research. The author studies research documents like papers and works related to experimental teaching of sports health care, teaching reform of sports health care, physical education, education theory, sports statistics and so on, in order to provide theoretical basis for the experimental research in this paper.

Experimental control method. Students are grouped according to the actual situation of class teaching. 44 students of class 1 form the control group; 44 students of class 2 form the experimental group. The experiment teaching for experimental group students is conducted according to the experimental reform; the experiment teaching for control group students is conducted according to the traditional experimental mode. There are 48 teaching hours in one semester, of which experimental teaching accounts for 10 hours. After this semester, the learning effects of experimental group are compared with control group.

Questionnaire survey. A questionnaire named "Knowledge of Sports Health Care Experiment" is designed to investigate the degree of students' interests and recognition of experimental courses opened in this term.

Mathematical statistics. SPSS17.0 software is used to deal with all kinds of experimental data, and analyze the experimental results.

\section{Experimental Designs}

\subsection{Experiment content}

In order to facilitate the comparative analysis of experimental results, the teaching contents of experimental group and control group are the same; while the organization and operation methods are different. 5 experiments are learned in this semester; including physical measurement and evaluation of physical burden, adult cardiopulmonary resuscitation, wound and bleeding bandaging, diagnosis and treatment of common sports injuries, and health care massage [4].

\subsection{Experimental method}

Table 1 Comparison of experimental methods between experimental and control groups

\begin{tabular}{|c|c|c|c|c|c|}
\hline & $\begin{array}{l}\text { Experiment 1: } \\
\text { physical measurement and } \\
\text { evaluation of physical } \\
\text { burden }\end{array}$ & $\begin{array}{l}\text { Experiment 2: } \\
\text { adult } \\
\text { cardiopulmonary } \\
\text { resuscitation }\end{array}$ & $\begin{array}{l}\text { Experiment } 3 \text { : } \\
\text { wound and bleeding } \\
\text { bandaging }\end{array}$ & $\begin{array}{l}\text { Experiment 4: } \\
\text { diagnosis and treatment } \\
\text { of common sports } \\
\text { injuries }\end{array}$ & $\begin{array}{l}\text { Experiment 5: } \\
\text { health care massage }\end{array}$ \\
\hline $\begin{array}{c}\text { Control } \\
\text { group }\end{array}$ & $\begin{array}{l}\text { Students are divided into } \\
\text { student group and test } \\
\text { group. The student group } \\
\text { needs to organize a } \\
\text { physical education class } \\
\text { and conduct the real } \\
\text { teaching. The test group } \\
\text { needs to measure, } \\
\text { calculate and evaluate one } \\
\text { to one. }\end{array}$ & $\begin{array}{l}\text { Study and practice } \\
\text { cardiopulmonary } \\
\text { resuscitation in the } \\
\text { laboratory. }\end{array}$ & $\begin{array}{l}\text { On the basis of video } \\
\text { play and teacher's } \\
\text { guidance, students } \\
\text { carry out the bandage } \\
\text { training between each } \\
\text { other in the classroom. }\end{array}$ & $\begin{array}{l}\text { According to knowledge } \\
\text { of diagnosis and } \\
\text { treatment of various } \\
\text { common sports injuries } \\
\text { explained in the } \\
\text { classroom, students } \\
\text { diagnose and treat the } \\
\text { injuries of each other. }\end{array}$ & $\begin{array}{l}\text { Students learn how to } \\
\text { massage in the laboratory } \\
\text { for } 2 \text { hours, and are asked } \\
\text { to practice in the } \\
\text { dormitory. }\end{array}$ \\
\hline $\begin{array}{l}\text { Experi- } \\
\text { mental } \\
\text { group }\end{array}$ & $\begin{array}{l}\text { The experimental group } \\
\text { goes to observe physical } \\
\text { education class in primary } \\
\text { school and carry out one to } \\
\text { one measurement, } \\
\text { calculation and evaluation } \\
\text { for pupils. }\end{array}$ & $\begin{array}{l}\text { After studying } \\
\text { cardiopulmonary } \\
\text { resuscitation in the } \\
\text { laboratory, students } \\
\text { are divided into } \\
\text { groups to go to } \\
\text { designated hospital } \\
\text { and observe the } \\
\text { rescue operation of } \\
\text { doctors. }\end{array}$ & $\begin{array}{l}\text { On the basis of } \\
\text { classroom video } \\
\text { teaching, students are } \\
\text { divided into groups to } \\
\text { go to the } \\
\text { Traumatology } \\
\text { Department of } \\
\text { designated hospital, } \\
\text { observe and dress } \\
\text { patients' wounds with } \\
\text { gauze under the } \\
\text { guidance of doctors. }\end{array}$ & $\begin{array}{l}\text { Students are divided } \\
\text { into groups to go to the } \\
\text { Traumatology } \\
\text { Department of } \\
\text { designated hospital to } \\
\text { watch doctors' } \\
\text { diagnosis and treatment } \\
\text { of common sports } \\
\text { injuries. }\end{array}$ & $\begin{array}{l}\text { Students learn how to } \\
\text { massage in the laboratory } \\
\text { for } 2 \text { hours and open a } \\
\text { health massage laboratory. } \\
\text { Teachers regularly invite } \\
\text { the laboratory to do } \\
\text { massage, and students are } \\
\text { divided into groups to } \\
\text { practice at the laboratory. }\end{array}$ \\
\hline
\end{tabular}

Note: In Experiment 1, the experiment group students go to observe PE class in Linyi Yilongwan Experimental Primary School 


\subsection{Assessment and evaluation}

There are many methods to evaluate the experiment, including the comparison of students' interests in the form of experiments, their conscious participation of experiments, the grades of experimental reports, and students' practical abilities.

\section{Experiment Results and Analysis}

\subsection{Students' interests in the form of experiment}

The experimental group and the control group are selected and do the same experiment in different forms. Afterwards, students from class 1 and class 2 are investigated by questionnaires to analyze the differences of their interests towards the experimental forms. The results are showed in Table 2.

Table 2. Comparison of students' interests in experimental forms (88 students)

\begin{tabular}{|c|c|c|c|c|c|c|c|c|c|c|}
\hline \multirow{3}{*}{$\begin{array}{l}\text { Control } \\
\text { group }\end{array}$} & \multicolumn{2}{|c|}{ Experiment 1} & \multicolumn{2}{|c|}{ Experiment 2} & \multicolumn{2}{|c|}{ Experiment 3} & \multicolumn{2}{|c|}{ Experiment 4} & \multicolumn{2}{|c|}{ Experiment 5} \\
\hline & Number & $\%$ & Number & $\%$ & Number & $\%$ & Number & $\%$ & Number & $\%$ \\
\hline & 42 & 48 & 26 & 30 & 34 & 39 & 25 & 28 & 55 & 63 \\
\hline Experi- & Number & $\%$ & Number & $\%$ & Number & $\%$ & Number & $\%$ & Number & $\%$ \\
\hline group & 46 & 52 & 62 & 70 & 54 & 61 & 63 & 72 & 33 & 37 \\
\hline
\end{tabular}

Through the comparison of students' interest in Experiment 1, it can be found that 42 students are interested in the form of the control group, and 46 people are interested in the form of the experimental group. The difference is not significant. A part of students of the control group need to design and organize a real sports class on their own, while other students take the responsibility of measuring the physiological burden of the physical education class. This form allows some students to participate in the designing of experimental class, and meet their requirements of active participation. So many students have interests. Students in experimental group need to go to the primary school, and test pupils in a real physical education class. This test allows students to observe the PE class of primary school, so more than half of the students are more interested in it.

In Experiment 2, Experiment 3 and Experimental 4, students in the experimental group can observe the operation of doctors in hospital on the basis of their exercises in the laboratory or classroom; it can meet their curiosity. Moreover, they can experience the sense of urgency, tension and stress in the real rescue and treatment process, and learn more about doctors' medical diagnosis. Thus, most students are more interested in the form of experimental group. As high as $70 \%$ and $72 \%$ students are interested in Experiment 2 and Experiment 4, and 61\% students are interested Experiment 3.

Experiment 5 is the study of health massage. The difference between the control group and the experimental group is that control group students need to exercise on each other in the dormitory; while another group needs to exercise on teachers in the training laboratory. The survey results show that, $63 \%$ students are more interested in the form of control group; only 37\% students are more interested in the form of the experimental group. That is to say, students are more willing to practice with each other. Massage teachers will bring them pressure, and it makes them unhappy that they are not massaged by someone else.

\subsection{Students' conscious participation in the experiment}

The survey results of Experiment 1 show that, the participation rate of control group students is only $80 \%$, while the rate of experimental group is $91 \%$. One possible reason is that, control group students need to organize the physical education on their own. Therefore, there will be a part of students who do not obey the arrangement of class committee, and lead to disorder of classroom, as well as lazy students. Students in the experimental group do not need to organize sports class, and every student is tested. Almost every 3-5 minutes, they need to measure each pupil's heart rate and draw the chart, and calculate the physiological burden of PE class. So students are more careful, and 
their participation rate is high.

The result of Experiment 2, 3 and 4 show that, the participation rates of experimental group students are significantly higher than those of the control group. Interest is the best teacher, so students' participation rates are also higher. In Experiment 5, the participation rates of the two groups are high, indicating that students are more interested in the content of this experiment (Table 3).

Table 3. Comparison of students' conscious participation

\begin{tabular}{llllllllllll}
\hline & \multicolumn{2}{l}{ Experiment 1 } & \multicolumn{2}{l}{ Experiment 2 } & \multicolumn{2}{c}{ Experiment 3 } & \multicolumn{2}{c}{ Experiment 4 } & \multicolumn{2}{c}{ Experiment 5 } \\
\hline $\begin{array}{l}\text { Control } \\
\text { group (44 }\end{array}$ & Number & $\%$ & Number & $\%$ & Number & $\%$ & Number & $\%$ & Number & $\%$ \\
people) & 35 & 80 & 40 & 91 & 32 & 73 & 33 & 75 & 40 & 91 \\
& & & & & & & & & & & \\
$\begin{array}{l}\text { Experimenta } \\
\begin{array}{l}\text { group (44 } \\
\text { people) }\end{array}\end{array}$ & Number & $\%$ & Number & $\%$ & Number & $\%$ & Number & $\%$ & Number & $\%$ \\
& 40 & 91 & 43 & 98 & 38 & 86 & 41 & 93 & 41 & 93
\end{tabular}

Note: Experiment 2: the number refers to the number of experimental group students who go the hospital and observe doctors' rescue operation.

Experiment 2: the number refers to the number of control group students who really participate in classroom exercises.

Experiment 5: the number refers to the number of experimental group students and control group students who participate in 2 hours practice.

\subsection{The results of experimental reports}

The results of Experiment 1 show that the excellent and good rates of the experimental group are superior to those of the control group, and the disqualified rate is lower than that of the control group. It means more experimental group students have completed the experiment; they have relatively deep experimental experience, more seriously calculated experimental reports, and more deep analysis. Some students in the control group do not finish the experiment because of laziness. Therefore, some calculations of their experimental report are not correct. Errors and simple analysis lead to high disqualified rate (Table 4).

Table 4 Comparison of experimental report results of Experiment 1

\begin{tabular}{lllllllllll}
\hline & excellent & \multicolumn{1}{l}{ good } & \multicolumn{3}{l}{ pass } & \multicolumn{3}{l}{ disqualified } & \multicolumn{2}{l}{ total } \\
\hline $\begin{array}{l}\text { Control } \\
\text { group }\end{array}$ & Number & $\%$ & Number & $\%$ & Number & $\%$ & Number & $\%$ & Number & $\%$ \\
& & & & & & & & & & \\
$\begin{array}{l}\text { Experiment } \\
\text { al group }\end{array}$ & Number & $\%$ & Number & $\%$ & Number & $\%$ & Number & $\%$ & Number & $\%$ \\
& 10 & 32 & 18 & 41 & 8 & 18 & 4 & 9 & 44 & 100 \\
\hline
\end{tabular}

In Experiment 2, 3, 4 (table 5-7), the excellent and good rates of the experimental group are 79\%, $77 \%$ and $61 \%$, are higher than those of the control group, namely $66 \%, 59 \%$ and $50 \%$. The three experiments require experimental group students to go to the hospital and observe doctors' diagnosis, treatment and rescue. In practice, students can have better understandings about knowledge, and master medical skills better. Especially in Experiment 2, students need to observe the rescue process of medical staff, which gives them unforgettable experiences. Thus, they can analyze deeply in the experimental report, and get good scores.

The excellent and good rates of the experimental group and control group are all more than 50\%, which shows that students have strong interests, high participation rates and profound experiences in these three experiments. 
Table 5 Comparison of experimental report results of Experiment 2

\begin{tabular}{|c|c|c|c|c|c|c|c|c|c|c|}
\hline & \multicolumn{2}{|c|}{ excellent } & \multicolumn{2}{|l|}{ good } & \multicolumn{2}{|l|}{ pass } & \multicolumn{2}{|c|}{ disqualified } & \multicolumn{2}{|l|}{ total } \\
\hline \multirow[t]{2}{*}{$\begin{array}{l}\text { Control } \\
\text { group }\end{array}$} & $\begin{array}{l}\text { Numbe } \\
\mathrm{r}\end{array}$ & $\%$ & $\begin{array}{l}\text { Numbe } \\
\mathrm{r}\end{array}$ & $\%$ & Number & $\%$ & $\begin{array}{l}\text { Numbe } \\
\mathrm{r}\end{array}$ & $\%$ & Number & $\%$ \\
\hline & 11 & 25 & 18 & 41 & 8 & 18 & 7 & 16 & 44 & 100 \\
\hline $\begin{array}{l}\text { Experi- } \\
\text { mental }\end{array}$ & $\begin{array}{l}\text { Numbe } \\
r\end{array}$ & $\%$ & $\begin{array}{l}\text { Numbe } \\
\mathrm{r}\end{array}$ & $\%$ & Number & $\%$ & $\begin{array}{l}\text { Numbe } \\
r\end{array}$ & $\%$ & Number & $\%$ \\
\hline group & 20 & 45 & 15 & 34 & 6 & 14 & 3 & 7 & 44 & 100 \\
\hline
\end{tabular}

Table 6 Comparison of experimental report results of Experiment 3

\begin{tabular}{|c|c|c|c|c|c|c|c|c|c|c|}
\hline & excellent & & good & & pass & & disqualif & & total & \\
\hline \multirow{2}{*}{$\begin{array}{l}\text { Control } \\
\text { group }\end{array}$} & Number & $\%$ & Number & $\%$ & Number & $\%$ & Number & $\%$ & Number & $\%$ \\
\hline & 11 & 25 & 15 & 34 & 10 & 23 & 8 & 18 & 44 & 100 \\
\hline \multirow{2}{*}{$\begin{array}{l}\text { Experi- } \\
\text { mental } \\
\text { group }\end{array}$} & Number & $\%$ & Number & $\%$ & Number & $\%$ & Number & $\%$ & Number & $\%$ \\
\hline & 15 & 34 & 19 & 43 & 4 & 9 & 6 & 14 & 44 & 100 \\
\hline
\end{tabular}

Table 7 Comparison of experimental report results of Experiment 4

\begin{tabular}{lllllllllll}
\hline & excellent & & good & & pass & \multicolumn{3}{c}{ disqualified } & \multicolumn{2}{c}{ total } \\
\hline Control & Number & $\%$ & Number & $\%$ & Number & $\%$ & Number & $\%$ & Number & $\%$ \\
group & 8 & 18 & 14 & 32 & 14 & 3 & 8 & 18 & 44 & 100 \\
& & & & & 2 & & & & \\
$\begin{array}{l}\text { Experi- } \\
\text { mental }\end{array}$ & Number & $\%$ & Number & $\%$ & Number & $\%$ & Number & $\%$ & Number & $\%$ \\
group & 11 & 25 & 16 & 36 & 11 & 25 & 6 & 14 & 44 & 100 \\
\hline
\end{tabular}

In the survey it is found that, students' interests and participation in Experiment 5 are high at the beginning. But with the increasing times of practice, their interests and participation rates gradually reduce. It is also reflected in their experimental reports. The excellent and good rates of the experimental group and control group are $47 \%$ and $53 \%$, lower than the reports of other several experiments. The unqualified rates are as high as $27 \%$ and $30 \%$. It means students do not interest in the experiment any more, and their reports become careless (Table 8).

Table 8 Comparison of experimental report results of Experiment 5

\begin{tabular}{|c|c|c|c|c|c|c|c|c|c|c|}
\hline & excellent & & good & & pass & & disqualifi & & total & \\
\hline \multirow{2}{*}{$\begin{array}{l}\text { Control } \\
\text { group }\end{array}$} & Number & $\%$ & Number & $\%$ & Number & $\%$ & Number & $\%$ & Number & $\%$ \\
\hline & 6 & 14 & 17 & 39 & 9 & $0^{2}$ & 12 & 27 & 44 & 100 \\
\hline \multirow{2}{*}{$\begin{array}{l}\text { Experi- } \\
\text { mental } \\
\text { group }\end{array}$} & Number & $\%$ & Number & $\%$ & Number & $\%$ & Number & $\%$ & Number & $\%$ \\
\hline & 5 & 11 & 16 & 36 & 10 & 23 & 13 & 30 & 44 & 100 \\
\hline
\end{tabular}

\subsection{Students' practical abilities}

After the experimental teaching, the researcher randomly selects 10 students in the two classes and tests their performances on each experiment. The practical abilities of students are compared through completeness, proficiency, excellent and good rates and the unfinished rates.

For Experiment 1, 7 students of 10 in the control group are able to successfully complete, 3 of them are proficient, 1 of them is excellent, and 3 students do not complete. In the experimental group, 9 students complete, 6 proficient, 4 excellent, 1 unfinished, and the difference between the two groups is obvious (Table 9 ).

For Experiment 2, 9 people in the control group complete the experiment, 7 are proficient, 5 are excellent, and 1 does not complete. All students in the experimental group complete the experiment, 9 proficient and 7 excellent. Both groups have good performances, and the experimental group is better 
than the control group (table 10).

For Experiment 3 (Table 11) and Experiment 4 (Table 12), the experimental group is obvious superior to the control group in the degree of completion, proficiency degree, as well as excellent and good rates. In Experiment 5, the experimental group is slightly better than the control group in the degree of completion, proficiency degree, as well as excellent and good rates (Table 13).

Table 9. Students' practical abilities of Experiment 1

\begin{tabular}{lllllllll}
\hline & \multicolumn{2}{l}{ completeness } & \multicolumn{2}{l}{ degree of } & \multicolumn{2}{l}{ excellent and good } & \multicolumn{2}{l}{ unfinished } \\
& & & rates & & \\
\hline Control group & Number & $\%$ & Number & $\%$ & Number & $\%$ & Number & $\%$ \\
$\begin{array}{l}\text { (10 people) } \\
\text { Experimental }\end{array}$ & 7 & 70 & 3 & 43 & 1 & 14 & 3 & 30 \\
$\begin{array}{l}\text { group } \\
\text { (10 people) }\end{array}$ & 9 & 90 & 6 & 67 & 4 & 44 & 1 & 10 \\
\hline
\end{tabular}

Table 10. Students' practical abilities of Experiment 2

\begin{tabular}{|c|c|c|c|c|c|c|c|c|}
\hline & \multicolumn{2}{|c|}{ completeness } & \multicolumn{2}{|c|}{ degree of proficiency } & \multicolumn{2}{|c|}{ excellent and good rates } & \multicolumn{2}{|c|}{ unfinished } \\
\hline Control group & Number & $\%$ & Number & $\%$ & Number & $\%$ & Number & $\%$ \\
\hline (10 people) & 9 & 90 & 7 & 78 & 5 & 56 & 1 & 10 \\
\hline $\begin{array}{l}\text { Experimental } \\
\text { group }\end{array}$ & Number & $\%$ & Number & $\%$ & Number & $\%$ & Number & $\%$ \\
\hline (10 people) & 10 & 100 & 9 & 90 & 7 & 70 & 0 & 0 \\
\hline
\end{tabular}

Table 11. Students' practical abilities of Experiment 3

\begin{tabular}{|c|c|c|c|c|c|c|c|c|}
\hline & \multicolumn{2}{|c|}{ completeness } & \multicolumn{2}{|c|}{ degree of proficiency } & \multicolumn{2}{|c|}{ excellent and good rates } & \multicolumn{2}{|c|}{ unfinished } \\
\hline Control group & Number & $\%$ & Number & $\%$ & Number & $\%$ & Number & $\%$ \\
\hline (10 people) & 7 & 70 & 4 & 57 & 2 & 29 & & 30 \\
\hline $\begin{array}{l}\text { Experimental } \\
\text { group }\end{array}$ & Number & $\%$ & Number & $\%$ & Number & $\%$ & Number & $\%$ \\
\hline (10 people) & 9 & 90 & 7 & 78 & 5 & 56 & 1 & 10 \\
\hline
\end{tabular}

Table 12. Students' practical abilities of Experiment 4

\begin{tabular}{|c|c|c|c|c|c|c|c|c|}
\hline \multirow[b]{2}{*}{ Control group } & \multicolumn{2}{|c|}{ completeness } & \multicolumn{2}{|c|}{$\begin{array}{l}\text { degree of } \\
\text { proficiency }\end{array}$} & \multicolumn{2}{|c|}{ excellent and good rates } & \multicolumn{2}{|c|}{ unfinished } \\
\hline & Number & $\%$ & Number & $\%$ & Number & $\%$ & Number & $\%$ \\
\hline (10 people) & 8 & 80 & 5 & 63 & 4 & 50 & 2 & 20 \\
\hline $\begin{array}{l}\text { Experimental } \\
\text { group }\end{array}$ & Number & $\%$ & Number & $\%$ & Number & $\%$ & Number & $\%$ \\
\hline (10 people) & 9 & 90 & 7 & 78 & 6 & 67 & 1 & 10 \\
\hline
\end{tabular}

Table 13. Students’ practical abilities of Experiment 5

\begin{tabular}{|c|c|c|c|c|c|c|c|c|}
\hline & \multicolumn{2}{|c|}{ completeness } & \multicolumn{2}{|c|}{ degree of proficiency } & \multicolumn{2}{|c|}{ excellent and good rates } & \multicolumn{2}{|l|}{ unfinished } \\
\hline Control group & Number & $\%$ & Number & $\%$ & Number & $\%$ & Number & $\%$ \\
\hline (10 people) & 8 & 80 & 5 & 63 & 2 & 25 & 2 & 20 \\
\hline $\begin{array}{l}\text { Experimental } \\
\text { group }\end{array}$ & Number & $\%$ & Number & $\%$ & Number & $\%$ & Number & $\%$ \\
\hline (10 people) & 9 & 90 & 6 & 67 & 4 & 44 & 1 & 10 \\
\hline
\end{tabular}

\section{Discussions}

The new experimental teaching mode of "combination of sports and medicine" allows students to go into the hospital. Students can contact with patients directly and observe clinicians' diagnosis and treatment process. Compared with the traditional laboratory experiment, this teaching method helps students to understand the importance of medical skills better, and enables them to form different 
understandings on knowledge they have learned [5]. Field observation and doctors' guidance also help students to master clinical science and practical skills, which are powerful supplements to knowledge they learned at school, and will greatly improve the utilization rate of these skills in their future work and study.

In Experiment 1, the experimental group students are required to observe PE class in primary school and conduct the experimental operation. Judging from teachers' experience, this form makes students take the teaching content more seriously. Most students complete the experiment carefully. Control group students can design their own teaching content, but most of them are careless in the experiment. So their reports are worse than those of experimental group students.

Results of Experiment 5 show that, students are more willing practice massage skills with classmates. But the practical abilities of students in the experimental group are better than the control group. Although students are not willing to practice skills through massage their teachers in the laboratory, this kind of compulsive exercise makes them practice the massage skills more frequently. While in the dormitory there's no supervision, and the frequency of students' exercise is not high enough. Therefore, in the experimental teaching, it is necessary to consider both students' interests and the actual learning effects.

\section{Conclusions and Suggestions}

The results of this study confirms that, from the aspects of students' participation, interests, experiment report results and experimental skills mastery, the performances of students from the experimental group are better than the performances of students from the control group in the 4 experiments out of 5. It indicates that the modes of the experimental group are more suitable for students in our school. In future sports health care education, the new experimental teaching mode of "combination of sports and medicine" should be used more widely to help students grasp more practical skills at school.

In addition to the 5 experiments listed in this study, some selected experiments are also included in the course of sports health care. Among them, some experiments are more suitable for laboratory teaching. Therefore, apart from "combination of sports and medicine", "combination of indoors and outdoors" is also needed in the experimental teaching. The experiment modes should be diversified. More innovative experiments should be created to give full play to students' innovative thinking, so as to lay a solid foundation for innovative talents training.

\section{References}

[1] H.E. Yao, Sports Healthcare, Higher Education Press, Beijing, 2011.

[2] C. Li, the teaching reform of physical health education under the background of "cultivating applied talents", J. School Sports Science. 5 (2015).

[3] B.G. Bian, Research on experimental curriculum reform and efficiency assessment of sports healthcare, J. Fujian Sports Science and Technology. 3 (2009).

[4] H.E. Yao, et. al., Experimental Guidance of Sports Healthcare, revised ed., People's Sports Publishing House, Beijing, 2005

[5] Y.F. Guo, M.D. Xiao, Experiment teaching reform in sports healthcare of physical education major, J. Journal of Hunan University of Arts and Science (Science and Technology. 1 (2014). 